\title{
Monitoring Finnish family forestry
}

\author{
by Heimo Karppinen ${ }^{1}$ and Harri Hänninen²
}

\section{ABSTRACT}

Non-industrial private forestry is important in many European countries as well as in the United States and eastern provinces of Canada. Private forests are especially important in Finland because the forest industries are highly dependent on private timber supply. In this article, we present the Finnish monitoring system for private forestry. Forest owners receive mailed inquiries regarding demographics, holding characteristics, ownership objectives, areas of silvicultural treatments, and timber sales, as well as connections with extension organizations. Studies based on such data have been useful in planning and implementation of national forestry programs and policies.

Key words: non-industrial private forest owners, small-scale forestry, landowner characteristics, ownership objectives, forest management behaviour, timber supply, Finland

\section{RÉSUMÉ}

La foresterie sur terrain privé non-industriel est une activité importante dans plusieurs pays européens ainsi qu'aux ÉtatsUnis et dans les provinces de l'est du Canada. Les forêts privées occupent une place importante spécialement en Finlande car l'industrie forestière dépend grandement de l'approvisionnement en bois des terrains privés. Nous présentons dans cet article le système finlandais d'évaluation de la foresterie sur terrain privé. Les propriétaires de boisés privés reçoivent des sondages postaux portant sur des données démographiques, les caractéristiques de tenure, les objectifs des propriétaires, les superficies des traitements sylvicoles et les ventes de matière ligneuse, ainsi les contacts avec les services d'aide à la forêt privée. Les études découlant de données semblables ont été utiles au niveau de la planification et l'implantation de programmes nationaux et de politiques en foresterie.

Mots clés : propriétaires de boisés privés non industriels, foresterie à petite échelle, caractéristiques de la tenure, objectifs des propriétaires, comportement d'aménagement forestier, approvisionnement en matière ligneuse, Finlande

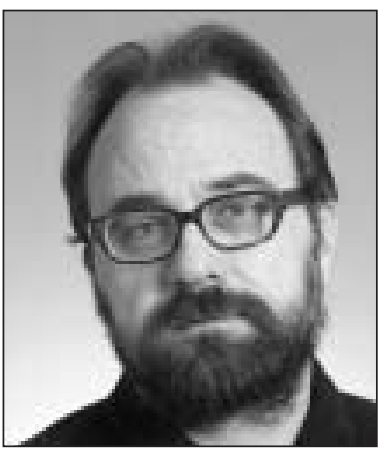

Heimo Karppinen

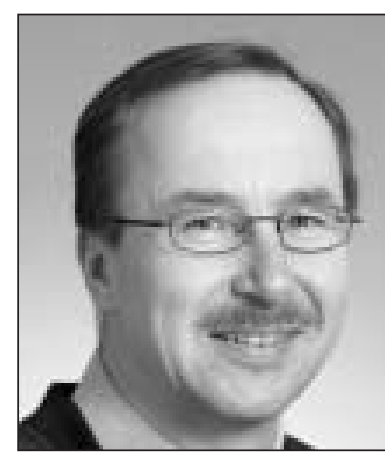

Harri Hänninen

\section{Family forestry at stake}

The importance of non-industrial private forestry (NIPF) varies by country. From the perspective of forest policy, the overarching issues are private timber supply and maintenance of biodiversity. Private forestry is of particular importance in many European countries, such as the Scandinavian countries, Germany and Austria, and many recently established democracies in Central and Eastern Europe. In the United States, non-industrial private forestry is concentrated in the eastern part of the country. In Canada, private forestry is particularly important in the east, in the Maritime Provinces.
Social changes in countries with substantial private forest areas are reflected in the characteristics of NIPF owners, their demographic features, objectives, and forest management behaviour. Forest owners are getting older, they live outside of their estates, and they are no longer engaged in agriculture. How do these changes affect the attitudes and behaviour of forest owners?

Various survey systems for monitoring private forestry have been developed in many countries. In the United States, the comprehensive National Woodland Owner Survey is conducted continuously (Butler and Leatherberry 2004). Separate survey studies have also been carried out in Europe (e.g., Lidestav and Nordfjell 1998, Bessières and René 2001, Kvarda 2004, Wiersum et al. 2005) and Canada (Environics 2000, 2001 in Hunt 2002). In this article, the Finnish monitoring system for private forestry is introduced.

\section{The role of private forests in Finland}

The Finnish economy is highly dependent on non-industrial private forests, which cover some $60 \%$ of the total forest area and provide around $70 \%$ of the roundwood used by exportoriented forest industries (Fig. 1). There are some 444000 NIPF holdings exceeding 2 ha of forest land (316 000 NIPF holdings $>5 \mathrm{ha})$. The number of owners is difficult to estimate because forests may be owned by single owners, by families together, or jointly by heirs (undistributed estates). There

\footnotetext{
${ }^{1}$ Dept. of Forest Economics, P.O. Box 27 (Latokartanonkaari 7) 00014 University of Helsinki, Finland. E-mail: heimo.karppinen@helsinki.fi ${ }^{2}$ Finnish Forest Research Institute, Unioninkatu 40 A, 00170 Helsinki, Finland. E-mail: harri.hanninen@metla.fi
} 


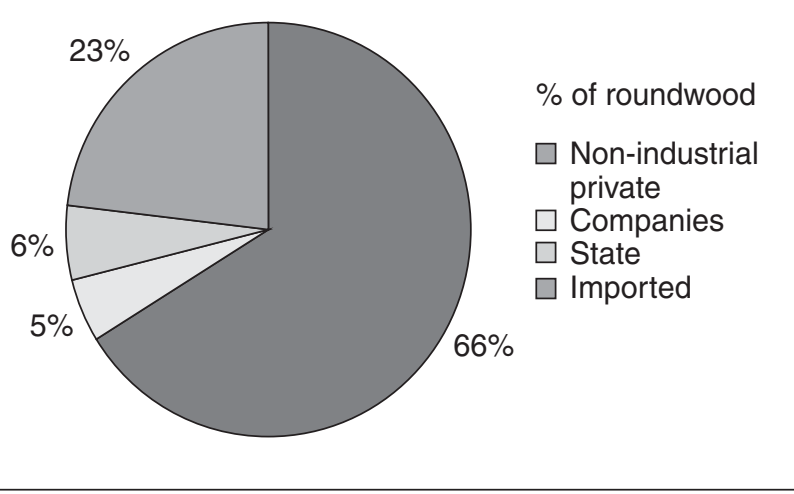

Fig. 1. Origin of roundwood used by Finnish forest industries in 2004. Source: Finnish Forest Research Institute and Finnish Forest Industries Federation.

is also another collective category - private partnerships. However, it is estimated that there are at least twice as many owners as there are forest holdings, and they own 12.2 million hectares of forest land.

The roots of private forestry in Finland can be traced back to the late 18th century, when the official demarcation of forests - the Great Partition - began. Since then, the redemption of leasehold properties in 1918, after the bloody Civil War, and the extensive settlement activities following the Second World War have had a tremendous impact on the structure of private forest ownership. Since the late 1960s, the changing economic structure of society, the exacerbation of regional development disparities, migration patterns, and urbanization have been the driving forces. The skewed age distribution of the population, which is common in the western countries, is also of concern to forest owners. These structural changes in the society are mediated mainly via the inheritance system; only $13 \%$ of estates are purchased in the free market.

Changes in ownership structure continued during the 1990 s, in some respects at an even faster pace. Changes in the structure of ownership have traditionally raised the threatening prospect of diminishing supplies of roundwood, as forest owners become less dependent on regular forest income and the objectives of forest ownership become more diverse. However, studies conducted over the last ten years have shown that the impacts of changes in ownership structure on forest management, especially on the supply of timber, have been quite modest.

\section{Monitoring system since the 1970s}

The first study on Finnish private forestry was conducted as early as 1935 (Osara 1935). The first significant step toward creating a permanent monitoring system for the whole country was taken in 1975 (Järveläinen 1978). It was followed by another study in Southern Finland during 1980-86 (Karppinen and Hänninen 1990), which also included inventories of sample woodlots. The third round of data collection was conducted in 1990, again dealing with the whole country (Ovaskainen and Kuuluvainen 1994), and it was followed by the latest survey in 1999 (Karppinen et al. 2002).
Earlier studies were based on areal sampling, due to a lack of representative registers on NIPF holdings. The sampling procedure was two-stage areal cluster sampling, where a holding's probability of inclusion in the sample was proportional to its total land area. Cluster sampling is a cost-effective method, especially for interview studies, because forest holdings are widely scattered and clustering saves on travel costs.

\section{Forest owner survey 2000}

The latest survey was based on the tax registers. The sample size was designed to provide regionally representative results, per Forestry Center (13), which is an administrative regional unit. The total sample consisted of 8800 holdings. The method used was stratified sampling according to forest size class in each region (Karppinen et al. 2002). The response rate to the mail inquiry was 55\% (4821 responses). The data collection procedure included three mailings - the last reminder by post card. The questionnaire was originally produced in Finnish, but it was translated into Swedish for the Swedish speaking minority on the coastline.

Forest owners were asked about demographics and holding characteristics as well as ownership objectives. Furthermore, the areas of silvicultural treatments and annual timber sales carried out during the five-year period preceding the inquiry were ascertained. Respondents were also asked about their connections with extension organizations and their information sources regarding forestry issues.

\section{A portrait of Finnish forest owners}

The main changes occurring in the structure of forest ownership in the 1990s were a decline in the number of farmer owners, an increase in the number of absentee owners, partly related to migration to urban areas, and an ageing of the forest owners (Fig. 2). Polarization has also taken place in the size distribution of forest holdings, which means increased numbers of both large and small holdings.

The proportion of forest owners who are active farmers declined during the 1990s, from one-third to one-fifth. This is no surprise, as the number of farms has decreased as a result, for example, of European Union (EU) membership. However, farmers still own a third of the total area under non-industrial private forestry.

Forest ownership by wage-earners and pensioners increased during the 1990s. Almost half of all forest owners are at least 60 years old, and only one in ten is under 40 . Indeed, the average age of forest owners has risen from 54 to 57.

In Finland, public discussion on private forest ownership has often exaggerated the proportion of forest owners who are city or town dwellers. In part, this is due to a blurring of the definition of urban areas, as many rural municipalities have officially become towns. A further reason may be that the rural-urban migration pattern of recent years has not affected forest owners to the same extent as the rural population at large. Despite the overall movement in Finland to cities and towns, 63\% of forest owners still live in sparsely populated rural areas and almost a fifth live in population centers or small towns. Only $19 \%$ of forest owners live in urban areas of more than 20000 inhabitants. Almost half of all forest owners reside permanently on their forest holdings, and two-thirds live in the same municipality. 
Occupational status

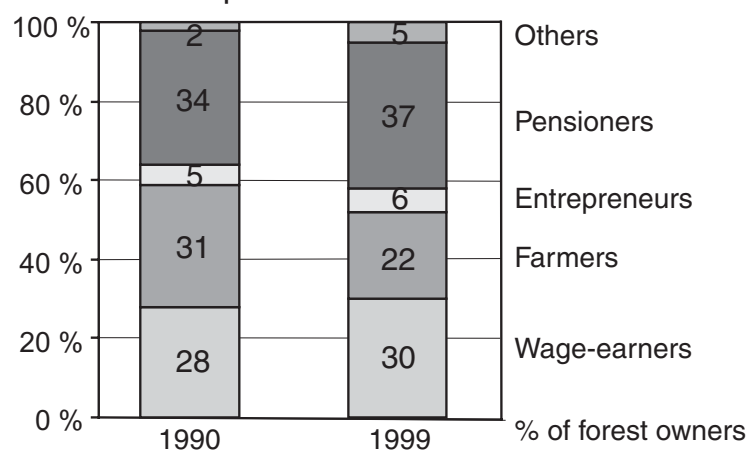

Place of residence

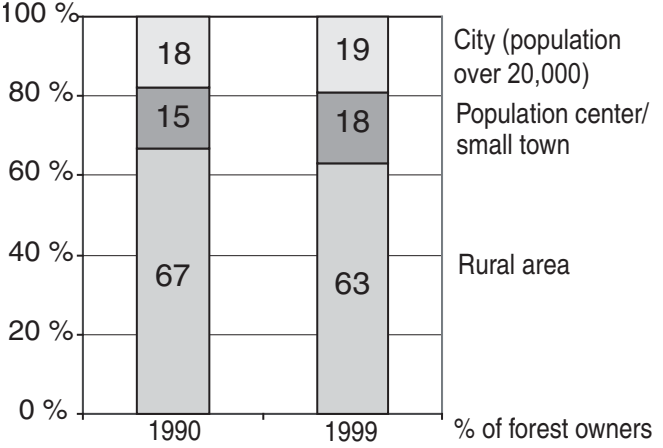

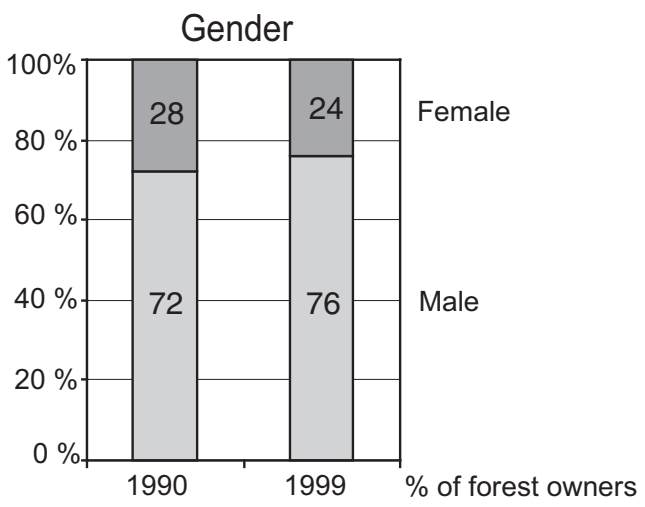
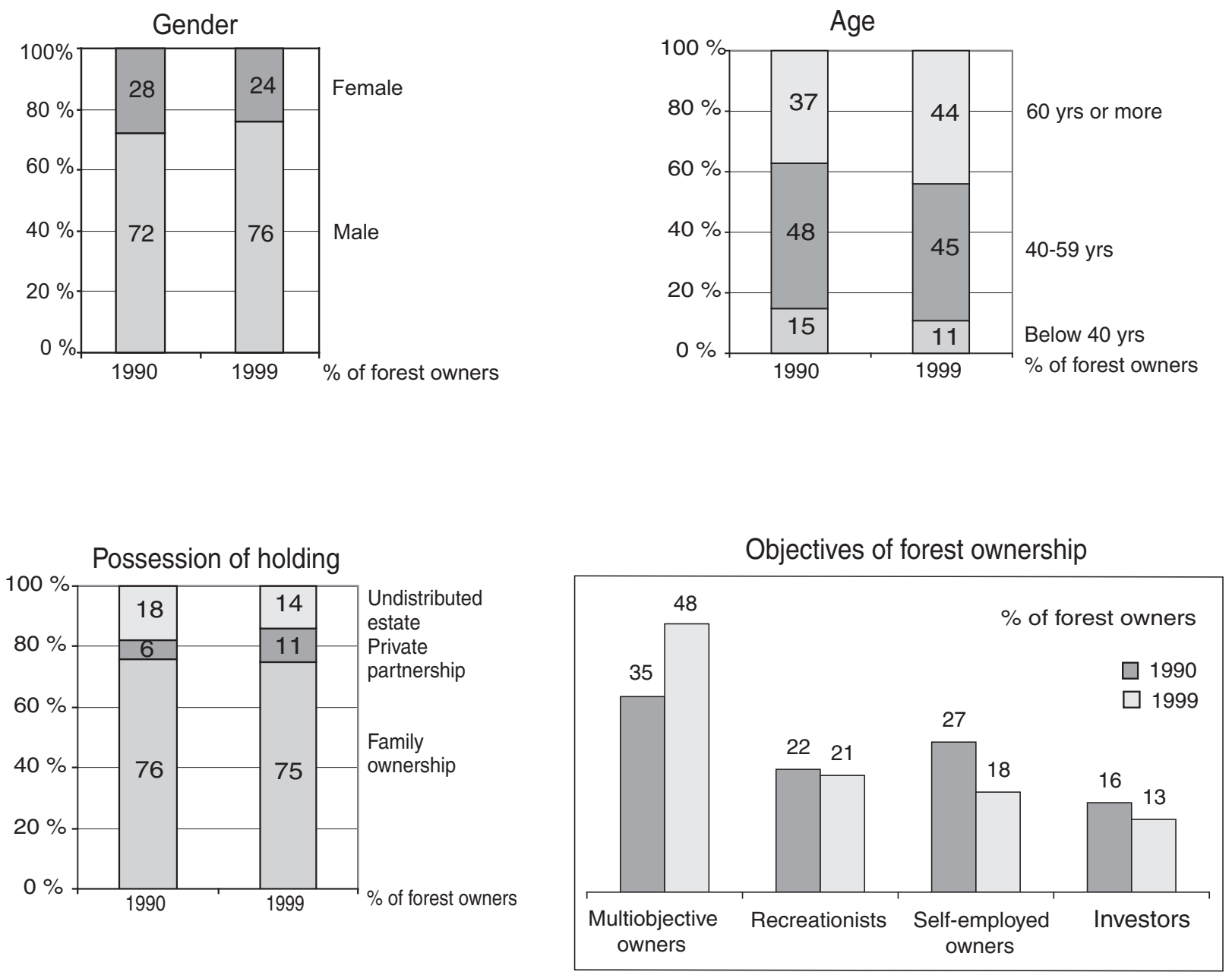

Fig. 2. Developments in NIPF ownership structure in Finland. Source: Karppinen et al. 200२. 


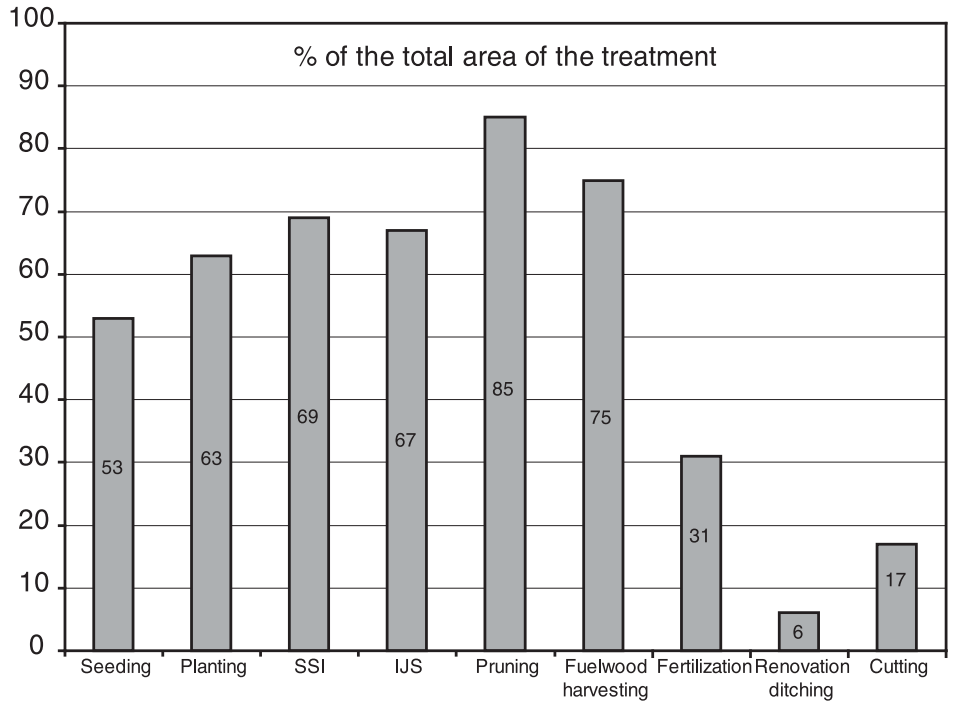

Fig. 3. Self-activity of forest owners in Finland. (SSI - seedling stand improvement, IJS - improvement of juvenile stands) Source: Koho et al. 2004.

The proportion of female forest owners has generally been rising along with changes in society at large. This trend has now levelled off and stabilized at one-quarter of all forest owners. The proportion did, in fact, decline slightly during the 1990s, despite women's higher-than-men's life expectancies and the rise in average age of forest owners. One possible explanation is the growing proportion of holdings that were once undistributed estates "controlled" by widows but which have subsequently been turned into private partnerships.

In Fig. 2, forest owners are clustered into four groups based on ownership objectives. The emphasis on multifunctionality increased during the 1990s. This can be seen in the rising proportion of multi-objective owners, who value both monetary and amenity benefits ( $48 \%$ of owners). The proportion of self-employed owners (18\%), who value labour income and employment provided by their forest, has diminished, as expected. Recreationists emphasize non-timber and amenity aspects $(21 \%)$ and investors regard their forest property as an asset and source of economic security, and as a source of regular timber sales income (13\%).

Forest owners' cuttings were, on average, $3.9 \mathrm{~m}^{3} / \mathrm{ha} /$ year during the period 1994-98, compared to $2.7 \mathrm{~m}^{3} / \mathrm{ha} /$ year in 1986-90. The period 1994-98 was, however, an era of economic boom. The diminishing effect of structural changes on roundwood supply cannot be detected. Farmers were the most active owner group, in terms of fellings. On the other hand, the use of own-family labour force in forest management (self-activity) is diminishing, although it is still at a high level (Fig. 3) (Koho et al. 2004). The same is probably true concerning forest owners' intensity of use of forestry extension services. Around $80 \%$ of forest owners had used personal professional assistance during the five-year period, every fifth owner had taken courses, and forest management plans were quite common (48\% of owners, $63 \%$ of NIPF forest area).

\section{Studies based on the monitoring system}

Forest owner surveys have provided versatile data on Finnish forest owners and their holdings. In combination with data from other sources, such as National Forest Inventory (NFI) and tax registers, a fairly extensive data set has been available for research purposes. The various studies based on these data have been useful in planning and implementation of national forestry programs and policies. Kuuluvainen et al. (1996), inter alia, studied ownership objectives and private timber supply using a Fisherian two-period consumption-savings model. A link was established between ownership objectives and observed harvesting behaviour. Multi-objective forest owners harvested significantly more than other - "singleobjective" - groups.

Favada et al. (2006) investigated the effects of stumpage prices and forest and landowner characteristics on long-run timber supply from private forests. The results supported the Faustmann rotation model when the forest owner simultaneously decides both the optimal rotation age of an even-aged stand and the optimal life-cycle consumption of goods and services with in situ valuation of standing timber.

On the other hand, Ovaskainen et al. (2006) analyzed the effect of cost-sharing on timber stand improvements in private forests, applying a two-period model with amenity values. Public subsidy, personal assistance, and forest planning increased the probability of stand improvements. Public subsidy, in particular, had substantial effects on both the probability and extent of investments.

\section{Future prospects}

The next data collection round will be in 2009. The study interval is prolonged because of the implementation of tax reform. The transition period from the old site-based tax system to the new sales tax system ended this year (2006). 
It is worthwhile waiting to see what will happen in the roundwood markets in the next couple of years. The delay in data collection is not a big concern because a number of minor surveys on private forest owners have served to update the basic demographics.

The monitoring data were collected earlier by interviews, and sample woodlots were inventoried or forest management plans were used. Due to diminishing research resources, the mail inquiry is at present the only option. However, this cannot provide reliable estimates of forest characteristics such as forest age distribution and timber volume or increment, which are important for analyzing forest management behaviour. For this reason, the integration of National Forest Inventory data on woodlots and the collected survey data on owners will be upgraded if at all possible (c.f. Butler and Leatherberry 2004).

The forthcoming survey will be based on several subsamples with specifically designed questionnaires. The basic items will be the same in each questionnaire type, enabling both countrywide and regionally representative estimates of family forest owners' demographic characteristics and behaviour. This arrangement provides data for several research topics at the same time, and it serves the basic function - a comprehensive review of Finnish private forestry.

The exchange of information concerning the various types of monitoring systems for private forestry can be useful. The pros and cons of different systems naturally vary. For instance, the US system produces information continuously and is closely connected to NFI, which can be considered strengths. In the Finnish system, data collection occurs more infrequently, but forest owners' behaviour is measured more accurately, which is a plus for forest policy planners.

\section{References}

Bessières, F. and J. René. 2001. La forêt privée morcelée. Agreste Primeur 90. 4 p.

Butler, B. J. and E.C. Leatherberry. 2004. America's family forest owners. J. For. 102(7): 4-9.

Favada, I.M., J. Kuuluvainen and J. Uusivuori. 2006. Consistent estimation of long-run nonindustrial private forest owner timber supply using micro data. University of Helsinki, Department of Forest Economics, Reports 40.29 p.
Hunt, L.M. 2002. Exploring the availability of Ontario's non-industrial private forest lands for recreation and forestry activities. For. Chron. 78(6): 850-857.

Järveläinen, V-P. 1978. Yksityismetsätalouden seuranta. Metsälöotokseen perustuvan tietojärjestelmän kokeilu. Summary: Monitoring the development of Finnish private forestry. A test of an information system based on a sample of forest holdings. Folia Forestalia 354.31 p. Karppinen, H. and H. Hänninen. 1990. Yksityistilojen hakkuumahdollisuuksien käyttö Etelä-Suomessa. Summary: Actual and allowable cut in nonindustrial private woodlots in southern Finland. Folia Forestalia 747. $117 \mathrm{p}$

Karppinen, H., H. Hänninen and P. Ripatti. 2002. Suomalainen metsänomistaja 2000. [Finnish forest owner 2000] Metsäntutkimuslaitoksen tiedonantoja $852.83 \mathrm{p}$.

Koho, R., H. Hänninen, H. Karppinen and V. Ovaskainen. 2004. Omatoimisuus metsätaloudessa. [Self-activity in nonindustrial private forestry]. Metsäntutkimuslaitoksen tiedonantoja 912. $41 \mathrm{p}$.

Kuuluvainen, J., H. Karppinen and V. Ovaskainen. 1996. Landowner objectives and nonindustrial private timber supply. For. Sci. 42(3): 300-309.

Kvarda, E. 2004. "Non-agricultural forest owners" in Austria - a new type of forest ownership. Forest Policy and Economics 6(5): $459-467$.

Lidestav, G. and T. Nordfjell. 1998. Med skogsägaren i fokus. [Private forest owner at stake] LRF Skogsägarna. 56 p.

Osara, N. 1935. Suomen pienmetsätalous. [Small-scale forestry in Finland] Communicationes Instituti Forestalis Fenniae 21.1. 427 p. Ovaskainen, V., H. Hänninen, J. Mikkola and E. Lehtonen. 2006. Cost-sharing and private timber stand improvements: A two-step estimation approach. For. Sci. 52(1): 44-54.

Ovaskainen, V. and J. Kuuluvainen. (eds.). 1994. Yksityismetsänomistuksen rakennemuutos ja metsien käyttö. [Structural changes in private forestry and the utilization of forests] Metsäntutkimuslaitoksen tiedonantoja 484. 122 p. + appendices.

Wiersum, K.F., B.H.M. Elands and M.A. Hoogstra. 2005. Smallscale forest ownership across Europe: characteristics and future potential. Small-scale Forest Economics, Management and Policy 4(1): 1-19. 